\title{
Assessment of the Use of Renewable Energy Sources for the Charging Infrastructure of Electric Vehicles
}

\author{
A. D. Gorbunova ${ }^{a *}$, I. A. Anisimov ${ }^{b}$ \\ ${ }^{a}$ Postgraduate Student, Department of Motor Transport Operation, Industrial University of Tyumen, Tyumen, Russian Federation \\ ${ }^{b}$ Professor, Department of Motor Transport Operation, Industrial University of Tyumen, Tyumen, Russian Federation
}

\begin{abstract}
Application of renewable energy sources is a relevant area of energy supply for urban infrastructure. In 2019 , the share of energy produced by such sources reached $11 \%$ (for solar energy) and $22 \%$ (for wind energy) of the total energy produced during the year. However, these systems require an improvement in their efficiency that can be achieved by introducing electric vehicles. They can accumulate, store and transfer surplus energy to the city's power grid. A solution to this problem is a smart charging infrastructure. The existing studies in the field of charging infrastructure organization for electric vehicles consider only models locating charging stations in the city or the calculation of their required number. These calculations are based on socio-economic factors and images of a potential owner of an electric vehicle. Therefore, the aim of this study is to develop a methodology for determining the location of charging stations and their required number. The calculation will include the operating features of the existing charging infrastructure, which has not been done before. Thus, the purpose of this article is to research the operation of the existing charging infrastructure. This will provide an opportunity to develop approaches to the energy supply of charging infrastructure and city's power grid from renewable energy sources. The article presents an analysis of data on the number of charging sessions during the year, month and day. This data enable us to construct curves of the charging session number and suggest ways to conduct the next stages of this study.
\end{abstract}

\section{Keywords:}

Renewable Energy Source;

Public Charging Infrastructure;

Electric Vehicle;

City's Power Grid;

Charging Sessions;

Chargers.

\section{Article History:}

$\begin{array}{llll}\text { Received: } & 03 & \text { September } & 2020 \\ \text { Accepted: } & 24 & \text { November } & 2020 \\ \text { Published: } & 01 & \text { December } & 2020\end{array}$

\section{1- Introduction}

Recently, the use of alternative energy sources, including power facilities in settlements, has become increasingly important [1,2]. At the moment, the share of electricity use from renewable sources is $26 \%$, including hydropower [3]. This type of energy is becoming more and more popular, and this is also the global energy agenda. The largest energy reserves are accumulated in solar and wind energy. Their share at the moment is in aggregate about $9 \%$ of the total amount of electricity generated [4]. Despite a $2.9 \%$ decrease in total power generation, solar and wind power generation increased by $33 \%$ combined [5].

However, the use of renewable energy sources in cities is connected with a number of problems associated with the presence of obstacles to the movement of air masses and shading when generating energy from solar panels. Electricity for consumers is not supplied from renewable energy sources directly, but rather from a buffer capacity, which is a storage battery. At the same time, a high-voltage battery of an electric vehicle can play a role of a buffer capacity. According to the analytical agency IRENA, by 2030 the number of electric vehicles will have grown to 0.16 billion units [6]. This growth in electric vehicles will allow the creation of a V2G network and use the electric vehicle as a source of reserve power for the city's power grid. However, the implementation of this approach requires the development of smart charging infrastructure that supplies energy to the power grid of the city.

\footnotetext{
*CONTACT: Gorbunovaad94@gmail.com

DOI: http://dx.doi.org/10.28991/esj-2020-01251
}

(C) 2020 by the authors. Licensee ESJ, Italy. This is an open access article under the terms and conditions of the Creative Commons Attribution (CC-BY) license (https://creativecommons.org/licenses/by/4.0/). 
The accelerated growth in electric vehicle numbers has led to the need to develop charging infrastructure for electric vehicles [7, 8]. The leaders in the construction of charging infrastructure are the Netherlands, where there is one charging station per $5 \mathrm{~km}$ of the road [9]. In general, there are now 5 million charging stations in the world, 10\% of which are public [5]. This indicates that, in general, the charging infrastructure in cities is not well developed, especially in Russia. 90\% of charging stations are created by electric car owners; they are slow and privately owned. This can lead to peak loads in the evening when electric vehicles are massively charged from slow charging stations [10]. These problems indicate that when public charging infrastructure is created, it is necessary to use electric vehicles as temporary energy storage devices that can be connected to a single power grid and smooth out peaks in electricity consumption. Therefore, the creation of a public charging infrastructure is a prerequisite for the development of electric vehicles.

Existing research related to the development of charging infrastructure includes issues related to determining the location of the charging station for electric vehicles and their number [11, 12]. The research is based on the following factors: distance to the power plant for both the driver and the electric vehicle. Their number is determined mainly by socio-economic factors [13]. An analysis of the correct functioning of an existing charging station is usually not considered. Some of the authors confirm the need for a deep analysis of the functioning of the existing charging infrastructure $[14,15]$. An analysis of the operation of the existing charging infrastructure will allow us to find errors and approach the formation of the future charging infrastructure for electric vehicles more correctly. This study is aimed at developing correct approaches to the formation of charging infrastructure and determining the number of charging stations and their installation locations. The study will include an analysis of the existing charging network in a specific locality. It will be based not only on the image of a potential owner of electric vehicles, but also on the features of the existing charging infrastructure operation.

The purpose of this article is to present approaches to the formation of an urban charging network for electric transport, taking into account the possibilities of obtaining power from renewable sources and taking into account the existing charging points for electric vehicles.

\section{2- Literature Review}

The use of RES can be used to reduce the negative impact on the power grid during the period of maximum electricity consumption. Bernie D.P. considers the use of solar-powered charging stations in areas of high concentration of people $[16,17]$. There are a number of studies considering retrofitting a household's power grid with RES in order to compensate for peak loads in the grid in the evening. They examine the balance between electricity from a standard grid and electricity supplied to a household from electric vehicles [18, 19]. The results of these studies indicate that the use of electric vehicles as a buffer capacity can reduce the consumption of electricity from the network at peak times by a third [20].

The use of distributed energy elements in a standard power grid, to which electric vehicles can be classified, is a promising area of research in the creation of SmartGrid [21]. These systems will allow the integration and management of all elements of the city's power system and charging infrastructure, in particular. The current unpredictable charging of electric vehicles at any time can lead to shifts in peak loads for which the city's grid may not be prepared [22]. Reducing this impact is possible with the use of scientifically based approaches to the charging time of cars.

The influence of the charging infrastructure on the load of the city's power grid is changed by selecting its optimal type (fast charging stations/battery swap, home charging stations, public charging stations/workplaces) [23]. This approach is applied when designing a charging network, using its elements in specific places in the city. In operation, the adaptive control of car charging using time series is considered, taking into account the convenience of owners of electric vehicles in terms of car charging [24]. Shahid et al. (2012) and Simonov (2011) [25, 26] considered the estimation of the time of connecting electric vehicles to the charging infrastructure using integrated sensors, both in a charging station and in an electric vehicle. The same devices, connected with a single control center, will make it possible to correctly charge a fee for using the charging infrastructure. These devices also provide a differential charge of batteries or transfer energy back to the city's electric network. In this case, rate regulation is implemented by modeling a multilayer market [27]. In this case, it is proposed to implement tariff regulation by modeling a multilayer market, which will include aggregators (sellers of energy from the power grid), owners of electric vehicles (sellers of energy to aggregators), and elements of a smart city energy system (buyer of electricity). Research data confirm that this approach is more efficient than the conventional use of electric vehicles. But Drude et al. (2014) noted that the implementation of this approach requires strict regulation of rates [28]. This paper proposes strict tariff regulation in the emerging market. Lack of such regulation will cause a decrease in electricity prices.

The functioning of the proposed technologies is possible only when using renewable sources as an energy source. P. Kumar, M. Singh and I. Kar presented a device for the introduction of charging infrastructure in the smart city grid [29]. It can change the battery charging rate depending on its condition. In the work of Garkynak and Khaligh (2009), 
a home charging system from RES is proposed, operating in a test mode in Chicago, Illinois [30]. Carli and Sheldon (2013) [31] focuses on taking into account the physical and electrical characteristics of alternative energy sources to create a charging infrastructure.

The use of renewable energy sources will not only reduce peak loads on the power grid, but also lead to lower costs during the operation of charging stations [32]. The introduction of photovoltaic panels and a wind generator into a fast charging station enabled. According to Apajalahti et al. (2017) and Pan et al. (2010) [33, 34] studies, the use of a wide range of energy technologies will allow organizations of various profiles to be involved in the process of creating a charging infrastructure.

The correct functioning of the network of charging stations is based on the method of determining their location, depending on a number of factors. In Kibaara et al. (2020) and Pashajavid and Golkar (2013) [35, 36] studies, it is noted that the places of installation of charging stations with renewable energy sources should take into account the minimum losses from the energy source to the charging station. The calculation of the number of such charging stations and their total capacity is carried out on the basis of the theory of queuing systems and simulation of the features of their functioning $[37,38]$.

Until now, no developed and tested methods have been found to determine the characteristics of the renewable energy charging infrastructure. The existing approaches do not use the data of the created charging infrastructure, which could provide a basis for analyzing the lower costs for their operation and operation of electric vehicles [39, 40]. They did not consider the features of the existing network of charging stations. But this approach enable reducing capital costs for owners of infrastructure and operating costs for owners of electric vehicles. The patterns obtained in the work will be used to assess the possibility of connecting to the existing charging infrastructure with renewable energy sources. This will expand the results of Anisimov et al. (2018) [1].

\section{3- Research Methodology}

The performance of the charging infrastructure was analyzed on the basis of data from the cities in Russia where their number differs from the national average. The assessment is given taking into account the climatic features of Krasnodar, Yekaterinburg, and Vladivostok.

The initial data for the analysis are:

- The number of electric vehicles using public charging infrastructure;

- The time during the day at which the charging session is performed.

- The number of charging sessions performed by all stations during the day;

- The number of charging stations in the city;

- For the analysis, we used data from the PlugShare digital platform processed in Microsoft Excel.

The results of processing the received data were:

- Graphical dependence of changes in the number of charging sessions accounted for by public charging stations, taking into account the charging time and month of the year;

- Graphical dependence of changes in the number of charging sessions of electric vehicles in different months of the year;

- Graphical dependence of changes in the number of charging sessions of one electric vehicle during a month;

- Graphical dependence of changes in the operation factor of the charging station during the day.

These results will be used to select the number of renewable energy indicators for further research.

\section{4- Results and Discussion}

The charging session of electric vehicles during the day is not predictable and is random [41, 42]. To assess its random nature, their number was determined by months based on the PlugShare platform and presented via graphical dependencies, Figure 1. 


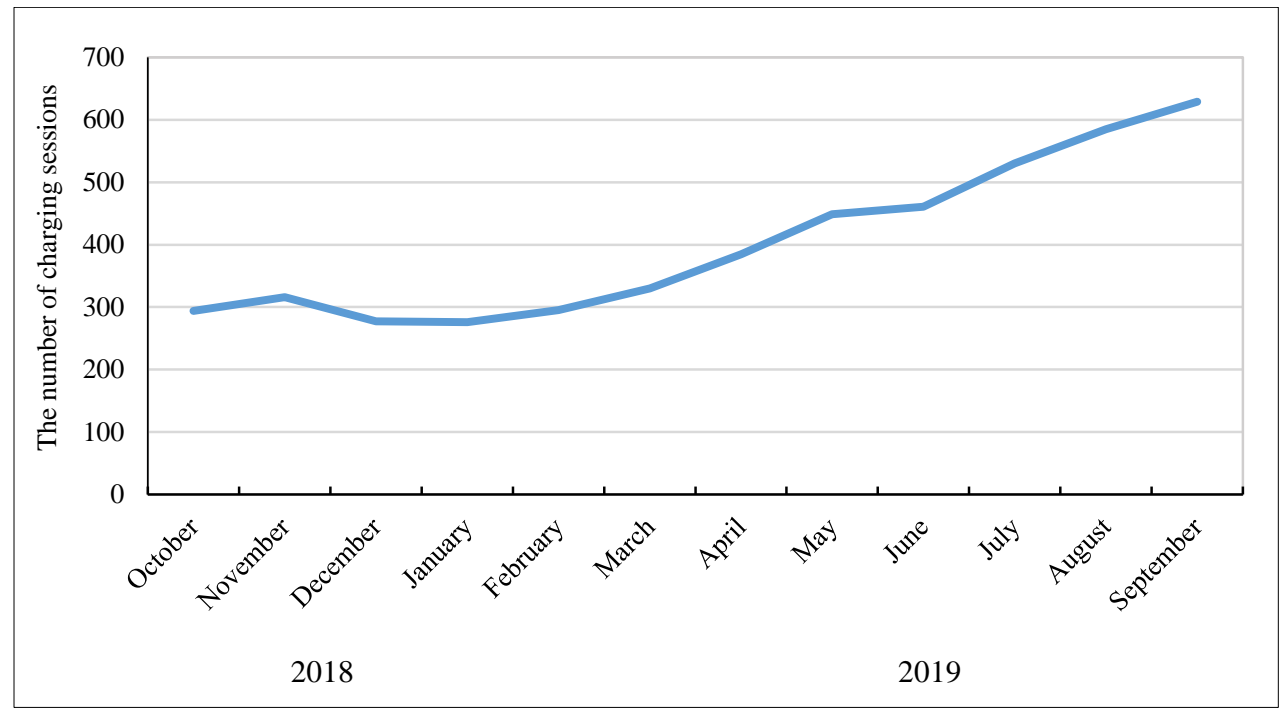

(a)

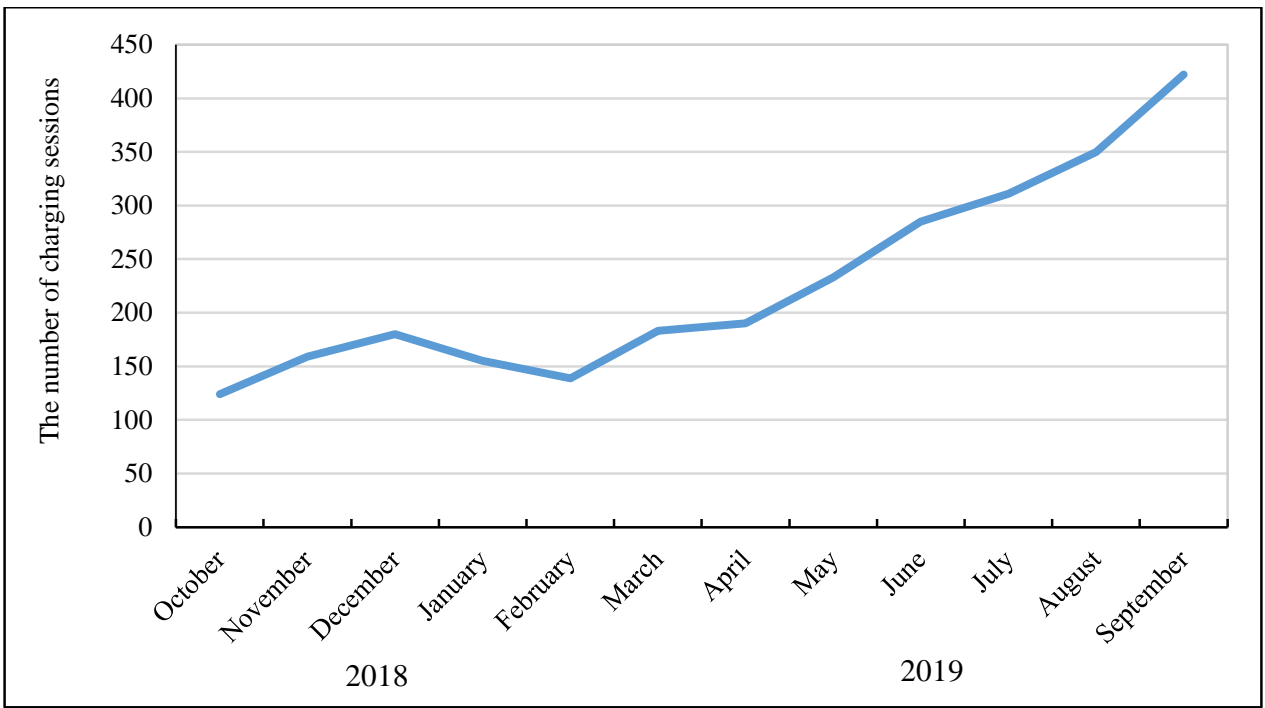

(b)

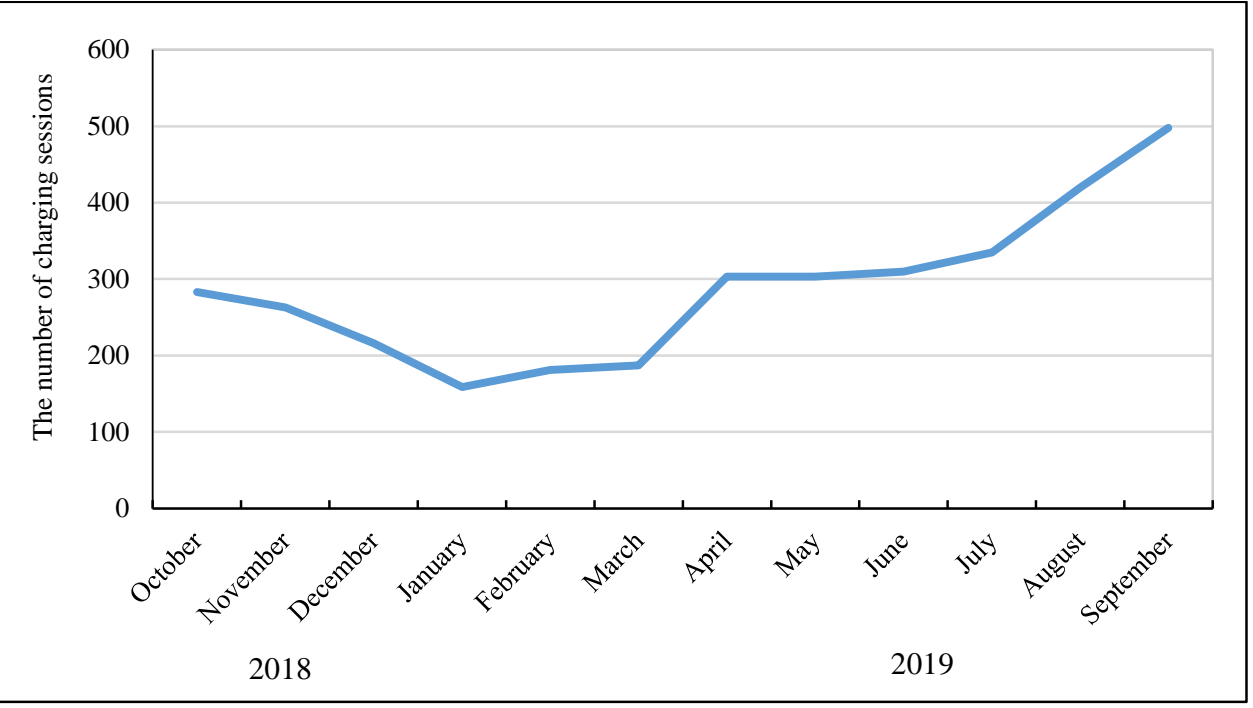

(c)

Figure 1. Curves of changes in the number of charging sessions performed by the public charging infrastructure during the year for: (a) Krasnodar; (b) Yekaterinburg; (c) Vladivostok.

Analyzing the data obtained, we came to the conclusion that with a decrease in air temperature, the number of charging sessions at public charging stations slightly decreases. The first conclusion that can be made by analyzing 
these dependences is that the number of electric vehicles in operation is reduced when the air temperature drops. However, after conducting the next series of studies, it was discovered that the number of electric vehicles charged in the winter period does not behave steadily; in some cities, it decreases, in some, it grows slightly. This is shown in the graphical dependences in Figure 2.

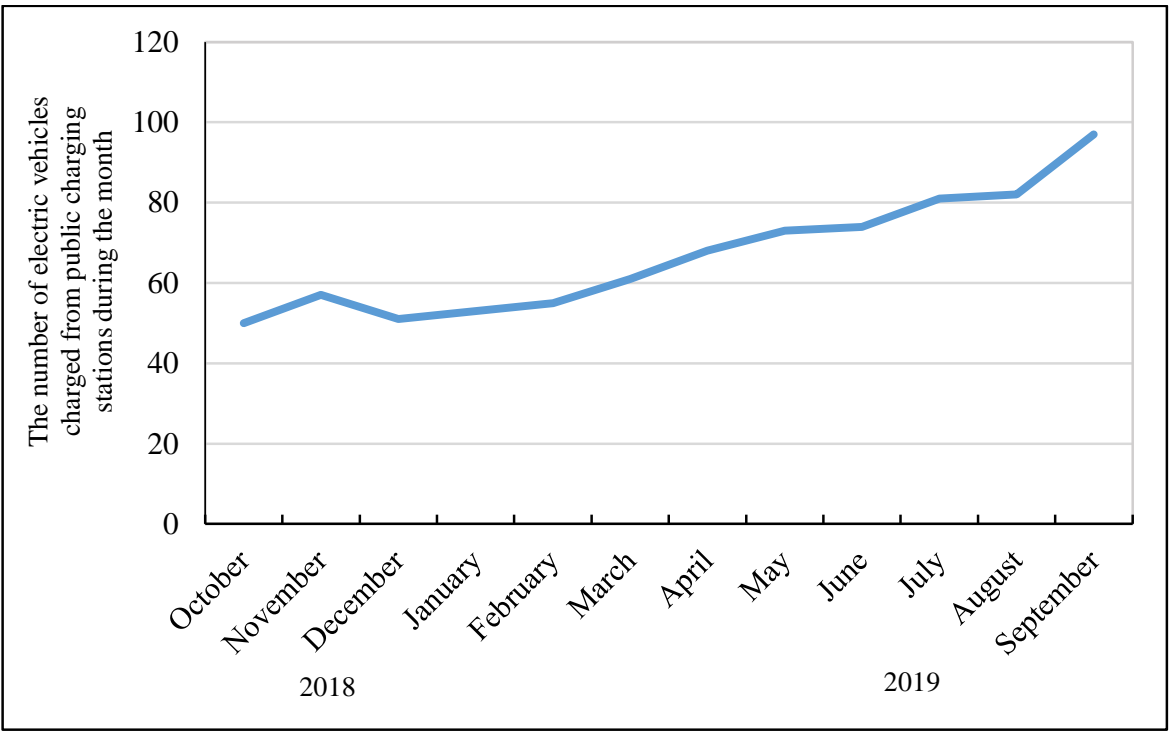

(a)

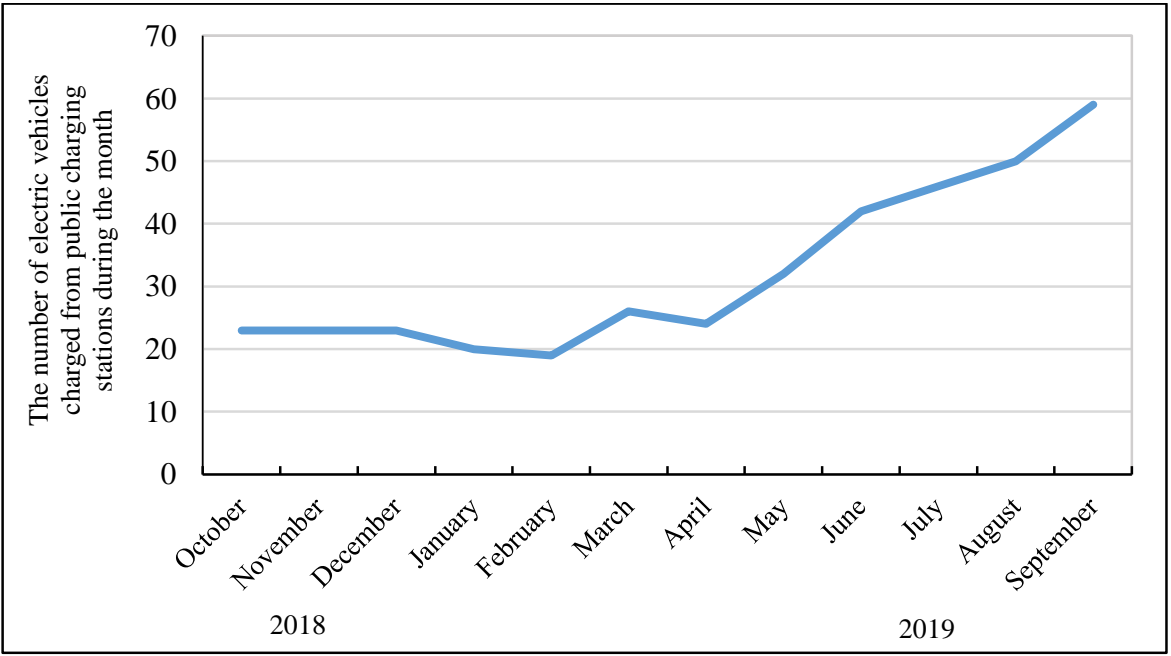

(b)

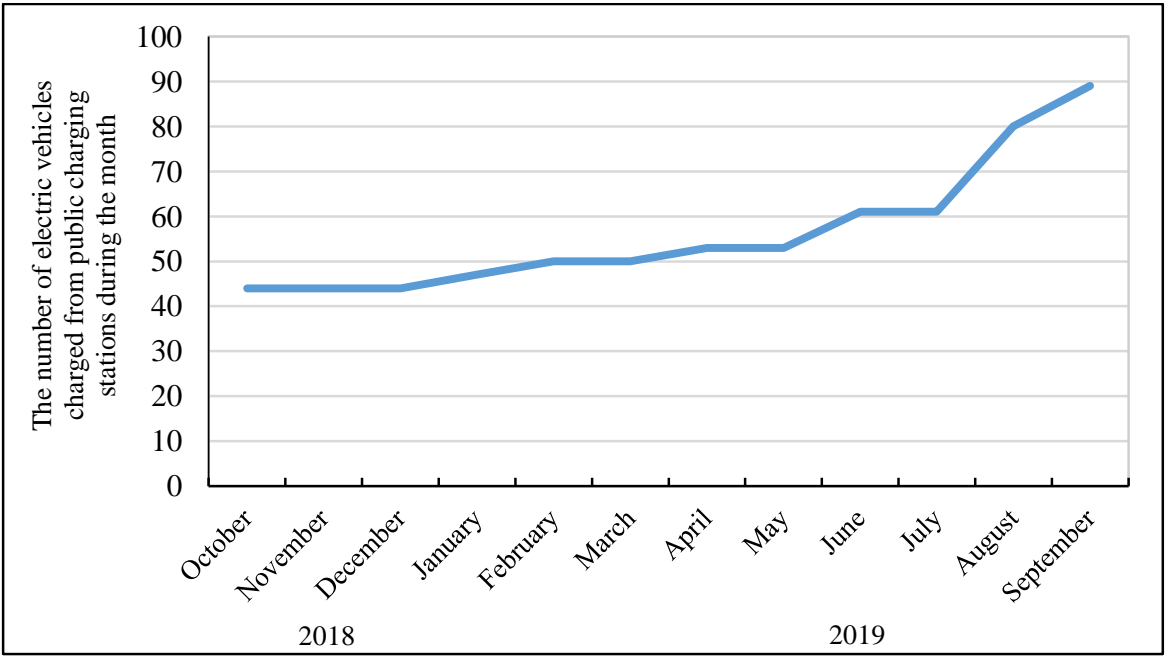

(c)

Figure 2. Curves of changes in the number of electric vehicles charged from public charging infrastructure in: (a) Krasnodar; (b) Yekaterinburg; (c) Vladivostok. 
In general, these fluctuations in the number of cars using charging stations in winter are in an insignificant range and it can be assumed that this number remains stable in winter. The same conclusion, about insignificant fluctuations, is confirmed by the data obtained by the authors in previous studies on the number of charging sessions of one electric vehicle per month and presented in Figure 3.

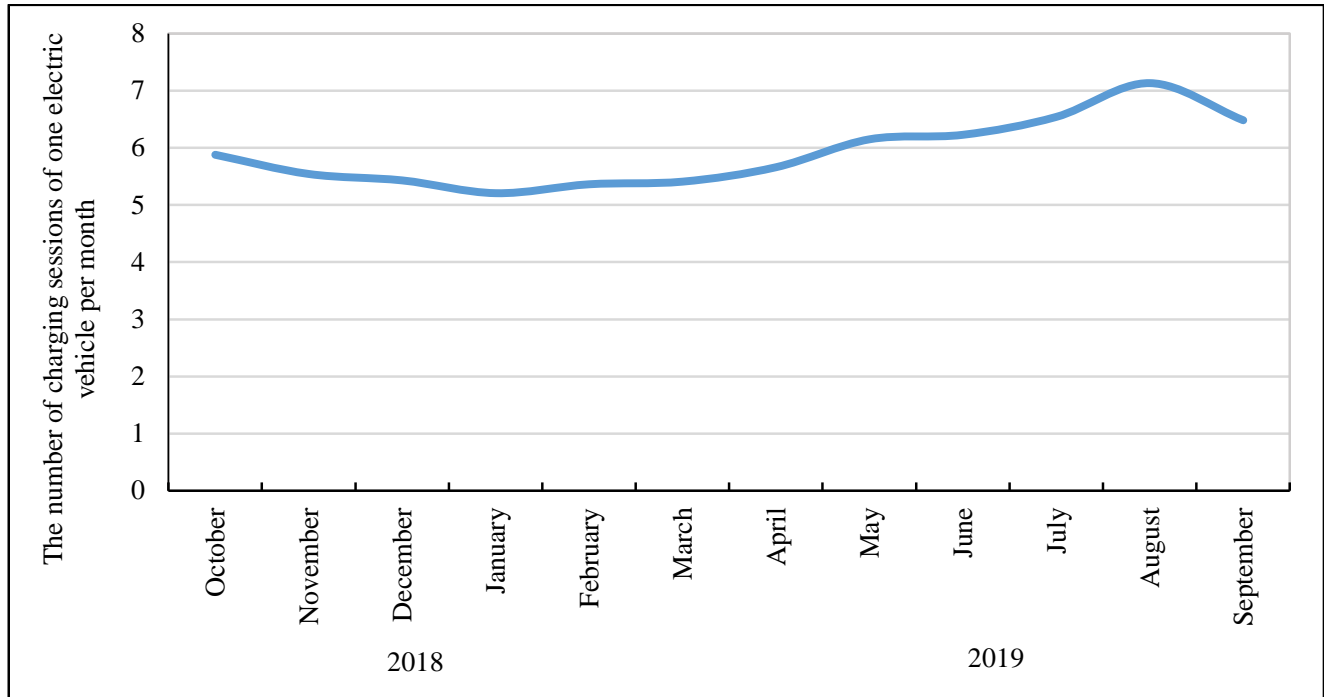

(a)

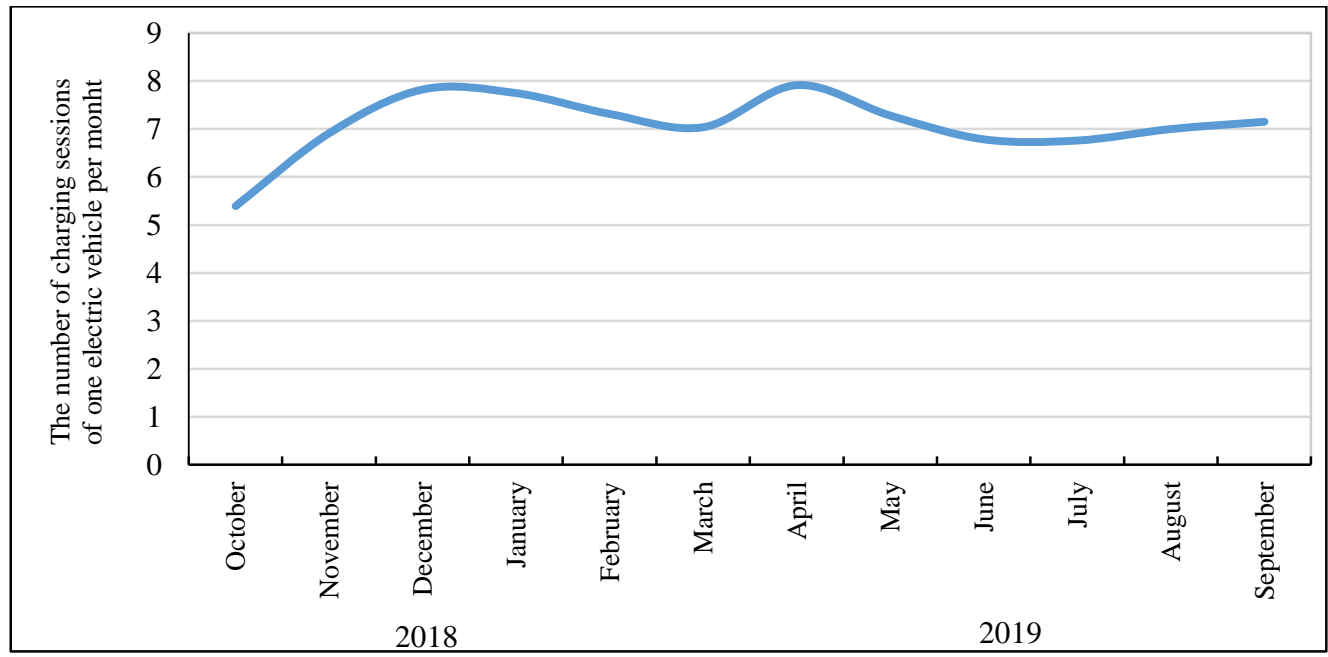

(b)

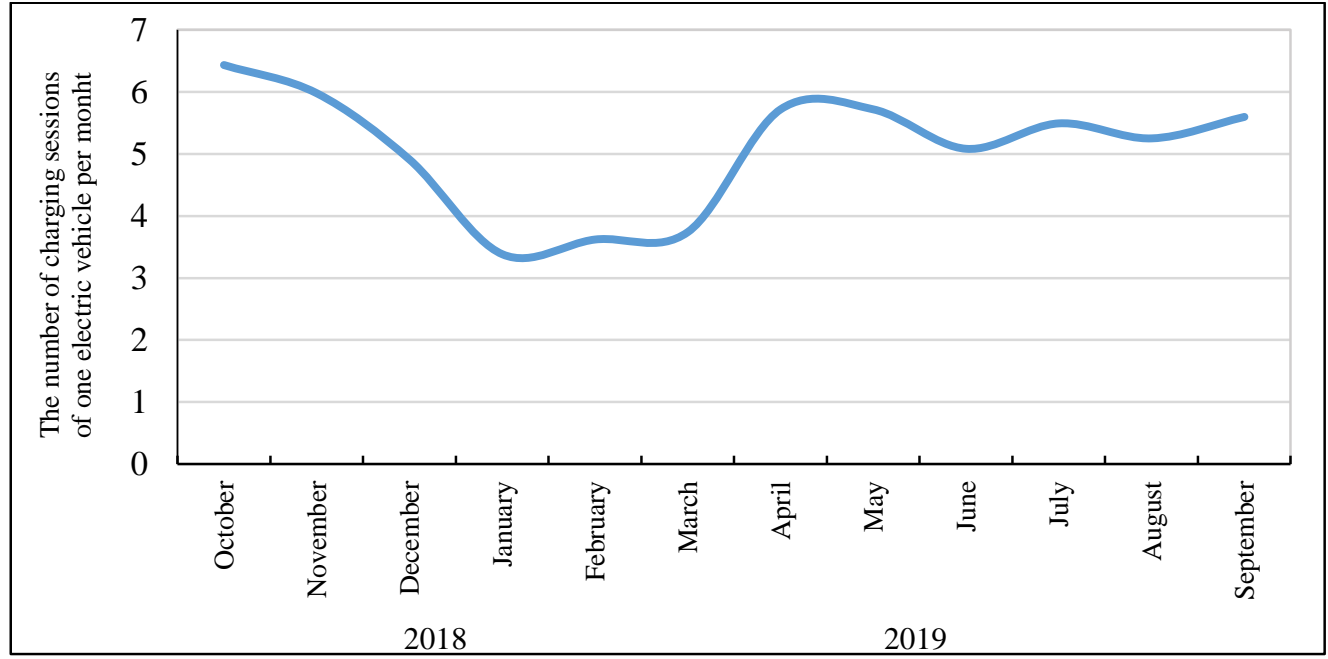

(c)

Figure 3. Curves of changes in the number of charging sessions performed by one electric vehicle, carried out by public charging infrastructure for a month in: (a) Krasnodar; (b) Yekaterinburg; (c) Vladivostok. 
Low air temperatures lead to a decrease in the number of charging sessions at public stations for one electric vehicle during a calendar month. It is logical that the number of charging sessions from the home grid increases. This is due to the fact that low air temperatures cause longer battery charging times, which becomes uncomfortable for electric vehicle users. They begin to actively charge the electric car from the home grid at night.

In the future, the patterns obtained will allow us to make a more correct choice of renewable energy sources, directing an even distribution of demand for the winter period. It is the winter period for regions north of 50 degrees north latitude that is problematic in terms of power generation.

The use of renewable energy sources can be widely used when a forecast is made about the time of active use of the public charging infrastructure for a particular city. Figure 4 shows graphical dependences describing the regularity of the change in the operation factor of the charging station during the day.

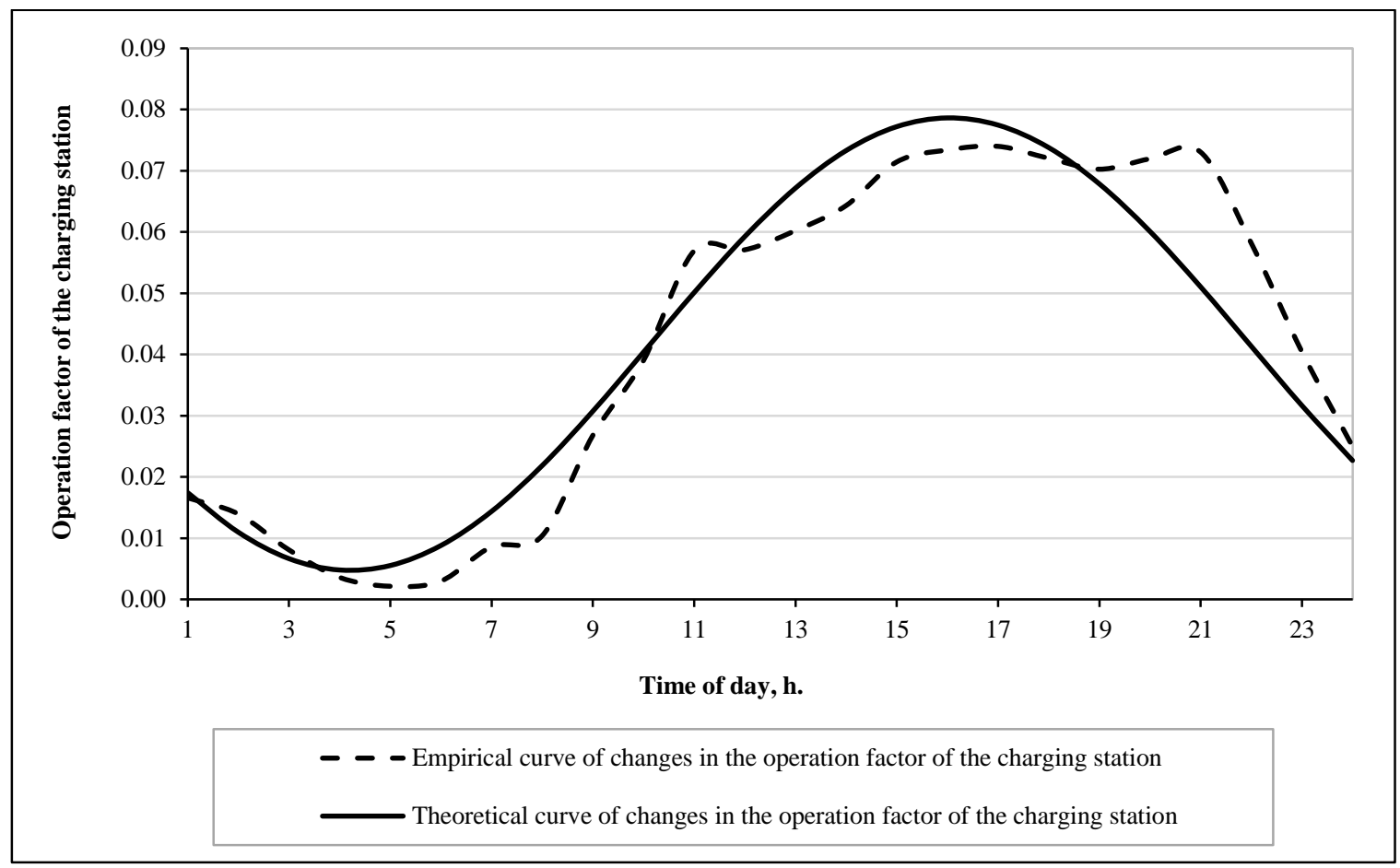

Figure 4. Curves of changes in the operation factor of charging stations during the day.

The results of the analysis of the distribution of charging sessions during the day allowed us to conclude that the peak of charging sessions occurs in the daytime. This fact confirms that even in the northern regions the use of renewable energy sources to supply energy to the charging infrastructure is possible. The power supply of charging stations at night is possible in three ways: from a wind generator, from a battery pack charged during daylight hours, and from electric vehicles that have surplus electricity in the battery. However, a detailed study of the results indicated that a great utilization rate of the charging sessions is observed in the evening. In this case, the energy supply of the charging infrastructure from renewable energy sources can be difficult [24]. It is due to the fact that the electric vehicle must transfer surplus energy to the city's electric network in the evening. For uniform consumption of electricity from renewable energy sources at charging stations, it is necessary to encourage owners of electric vehicles to charge their vehicles during daylight hours from 9 to 16 hours. This can be achieved through the application of differentiated tariffs.

\section{5- Discussion}

In this study, we analyzed the articles that let us evaluate the proposals given in these articles, the features taken into account when organizing the process, the advantages and disadvantages that are based on the opinion of the authors. Table 1 shows the articles closest to the area of our research and their analysis. 
Table 1. Analysis of publications on the use of renewable energy sources in the organization of electric vehicles charging sessions.

\begin{tabular}{|c|c|c|c|c|}
\hline $\begin{array}{l}\text { Research } \\
\text { work }\end{array}$ & $\begin{array}{l}\text { Proposals for the organization of } \\
\text { charging infrastructure for electric } \\
\text { vehicles using renewable energy } \\
\text { sources }\end{array}$ & $\begin{array}{c}\text { Features considered at the } \\
\text { organizing stage }\end{array}$ & $\begin{array}{c}\text { Advantages (according to the } \\
\text { authors) }\end{array}$ & $\begin{array}{l}\text { Disadvantages } \\
\text { (according to the } \\
\text { authors) }\end{array}$ \\
\hline $\begin{array}{l}\text { Birnie (2009) } \\
{[17]}\end{array}$ & $\begin{array}{l}\text { Application of charging stations } \\
\text { with photovoltaic systems for } \\
\text { electric vehicles in places of work. }\end{array}$ & $\begin{array}{l}\text { Provided range of electric } \\
\text { vehicles. Cost of a solar system } \\
\text { with a charging station and its } \\
\text { payback. Number of electric } \\
\text { vehicles in operation. } \\
\text { Organization of parking } \\
\text { spaces. }\end{array}$ & $\begin{array}{l}\text { Reduced peak load on the city's } \\
\text { power grid in the evening as a } \\
\text { result of replenishing the charge } \\
\text { of the TAB battery of electric } \\
\text { vehicles in the daytime and the } \\
\text { possibility of its return in the } \\
\text { evening. }\end{array}$ & $\begin{array}{l}\text { Long payback } \\
\text { period for charging } \\
\text { infrastructure. } \\
\text { Large area occupied } \\
\text { by photovoltaic } \\
\text { panels }\end{array}$ \\
\hline $\begin{array}{l}\text { Gurkaynak } \\
\text { and Khaligh } \\
(2009) \text { [30] }\end{array}$ & $\begin{array}{l}\text { Application of charging stations for } \\
\text { electric vehicles with the ability to } \\
\text { return energy to the grid in } \\
\text { households }\end{array}$ & $\begin{array}{l}\text { Household power grid load } \\
\text { profile. Annual data on solar } \\
\text { radiation. Characteristics of the } \\
\text { equipment used when } \\
\text { organizing a charging station }\end{array}$ & $\begin{array}{l}\text { Reduced peak load on household } \\
\text { power grids by } 37 \% \text {. Meeting } \\
\text { the demand for electricity in the } \\
\text { household not only during the } \\
\text { day but also throughout the year }\end{array}$ & $\begin{array}{l}\text { High cost of the } \\
\text { system. Other } \\
\text { energy sources must } \\
\text { be introduced into } \\
\text { the developed } \\
\text { system to improve it } \\
\text { and ensure its } \\
\text { reliability. }\end{array}$ \\
\hline $\begin{array}{l}\text { Deilami et al. } \\
\text { (2011) [22] }\end{array}$ & $\begin{array}{l}\text { Application of the intelligent } \\
\text { charging infrastructure } \\
\text { management system }\end{array}$ & $\begin{array}{l}\text { Random nature of connecting } \\
\text { electric vehicles to a charging } \\
\text { station. } \\
\text { Voltage profile. } \\
\text { Losses and restrictions arising } \\
\text { from power generation. }\end{array}$ & $\begin{array}{l}\text { Actions of the participants in the } \\
\text { city's power system can be } \\
\text { coordinated. Reduced peak loads } \\
\text { on the city's grid }\end{array}$ & $\begin{array}{l}\text { Developed roposals } \\
\text { are available only } \\
\text { for "slow" charging } \\
\text { stations. }\end{array}$ \\
\hline
\end{tabular}

Dominguez- Application of fast charging stations for electric vehicles with (2019) [32] the integration of renewable energy
Station profitability. Amount of energy consumed. Charging time intervals for electric vehicles. State of the TAB battery of electric vehicles arriving for charging.
Increased profitability of the charging station and high power for fast charging of electric vehicles.
High capital costs Additional energy storage system is required
Hourly energy consumption of electric vehicles. Average daily vehicle mileage. Electricity storage technologies.

Constructive and technical parameters of the organized system.
Reduced costs and increased power generation from renewable sources in summer. Relatively short payback period of the system.
High volume of electricity onsumed in winter.
Selection of the optimal equipment

Sun et al. for charging stations, their optimal (2019) [44] location and calculation of the required number
Applied charging technologies for electric vehicles. Constructive and technical parameters of operated electric vehicles.
Increased profitability in the operation of charging infrastructure. Reduced time spent on using the charging infrastructure. Improved energy efficiency of the charging infrastructure and reduced load on the city's power system.

existing charging infrastructure.

A network of charging stations must be designed during organizing

The analyzed methods of organizing the charging infrastructure using renewable energy sources, except for Sun et al. (2019) [44], are based on the use of new technologies when creating a charging infrastructure.

The method described in Sun et al. (2019) [44] allows considering the introduction of changes in the existing charging infrastructure. However, this method requires a preliminary calculation of the number of charging stations and their location. This paper presents the results of calculating the number of charging stations.

The presented research analyzes the works related to approaches to determining the optimal number of charging stations and their location. This analysis is given in Table 2. 
Table 2. Analysis of publications on the location and number of charging stations for electric vehicles in cities.

\begin{tabular}{|c|c|c|c|}
\hline Research work & $\begin{array}{l}\text { Methods for calculating the } \\
\text { number of charging stations }\end{array}$ & $\begin{array}{l}\text { Advantages (according to the } \\
\text { authors) }\end{array}$ & Disadvantages (according to the authors) \\
\hline \multirow[b]{2}{*}{$\begin{array}{l}\text { Wang et al. } \\
(2013)[45]\end{array}$} & \multirow[b]{2}{*}{ Energy equivalence method } & \multirow{2}{*}{$\begin{array}{l}\text { Calculating the maximum } \\
\text { amount of energy that must } \\
\text { be generated to satisfy a fleet } \\
\text { of only electric vehicles }\end{array}$} & $\begin{array}{l}\text { No phased development plan for the charging } \\
\text { infrastructure. }\end{array}$ \\
\hline & & & $\begin{array}{l}\text { No possibility of calculating the required number of } \\
\text { charging stations for a limited number of operated } \\
\text { electric vehicles }\end{array}$ \\
\hline $\begin{array}{l}\text { Gimenez-Gaydou } \\
\text { et al. (2016) [12] }\end{array}$ & $\begin{array}{l}\text { Calculation based on the } \\
\text { image of a potential owner of } \\
\text { an electric vehicle }\end{array}$ & $\begin{array}{l}\text { Calculating the number of } \\
\text { charging stations based on } \\
\text { the image of a potential } \\
\text { owner of an electric vehicle } \\
\text { and drawing up a plan for a } \\
\text { gradual transition }\end{array}$ & $\begin{array}{l}\text { No adjustments and changes during the development of } \\
\text { the charging infrastructure. } \\
\text { No accounting for existing technologies used for } \\
\text { charging electric vehicles. }\end{array}$ \\
\hline $\begin{array}{l}\text { Wolbertus and } \\
\text { Hoed (2019) [46] }\end{array}$ & $\begin{array}{l}\text { Calculation of the number of } \\
\text { charging stations taking into } \\
\text { account data on the demand } \\
\text { for charging }\end{array}$ & $\begin{array}{l}\text { Calculating the number of } \\
\text { charging stations based on } \\
\text { data on the behavior of } \\
\text { electric vehicle owners and } \\
\text { their number }\end{array}$ & $\begin{array}{l}\text { No adjustments and changes during the development of } \\
\text { the charging infrastructure. } \\
\text { No accounting for existing technologies used for } \\
\text { charging electric vehicles. }\end{array}$ \\
\hline $\begin{array}{l}\mathrm{Li} \text { and } \mathrm{Su} \\
(2011)[38]\end{array}$ & $\begin{array}{l}\text { Calculation of the number of } \\
\text { charging stations based on } \\
\text { the queuing theory }\end{array}$ & $\begin{array}{l}\text { Accounting for data on the } \\
\text { fleet of electric vehicles and } \\
\text { the value of capital costs } \\
\text { required for the construction } \\
\text { of charging infrastructure. } \\
\text { Accounting for the } \\
\text { technologies used when } \\
\text { organizing the charging } \\
\text { infrastructure }\end{array}$ & $\begin{array}{l}\text { No accounting for the random nature of functioning of } \\
\text { the charging infrastructure }\end{array}$ \\
\hline
\end{tabular}

In this work, to take into account the features of the organization of the charging infrastructure, the method based on the queuing theory given by $\mathrm{Li}$ and $\mathrm{Su}$ (2011) [38] was applied. Firstly, because collecting data that do not account for the features of the functioning and operation of electric vehicles and the existing charging infrastructure is a complex process, and secondly, because the peculiarities of the applied charging technologies are not taken into account. In the specified method, we can do this by obtaining the patterns of changing the charging time of electric vehicles from the charging stations in operation. In doing so, we used a preliminary analysis of data on the functioning of the existing charging infrastructure.

The method based on the queuing theory has found wide application in studies related to the organization of the process of functioning of urban passenger transport. We use this approach to assess the characteristics of the charging infrastructure for electric vehicles. In the work of Conti et al. (2017) [40], the regularities of changes in the number and type of charging stations on the route depending on the average speed and parameters of bus occupancy are considered. According to the authors, this approach to planning the charging infrastructure leads to more efficient and less costly network operation. However, a number of authors, e.g. Fusco et al. (2013) [47], and others believe that the power consumption of an electric bus on the route depended on dynamic factors, the topography of the road, the length of the route, the volume of traffic on the route, and the operation of climatic equipment. De Filippo et al. (2014) [48] considered a different pattern and assessed the influence of the type and number of chargers on the power consumption of an electric bus. Thus, in the scientific world, there is no consensus on approaches to determining the optimal number of charging stations and their location. Therefore, studying the features of the existing charging infrastructure is one of the approaches used for further modeling of the network of charging stations.

\section{6- Conclusion}

Renewable energy sources can be widely used in charging systems for electric vehicles. The analysis of previously performed works led us to the conclusion that the widespread use of renewable energy sources for electric vehicles is actively discussed and applied. Their effective use can be based on their correct selection, taking into account the characteristics of the city, winter conditions, the number of charging stations, and their location.

The study made it possible to discover the dependences of changes in charging sessions during the year and the day. A decrease in the number of charging sessions is observed in the winter period, which may be due to an increase in the duration of charging an electric vehicle and a decrease in interest in public charging stations among electric car drivers. The efficient use of RES is possible when a larger number of charging sessions are shifted to daylight hours, which can be organized by applying a tariff approach. This will make it possible to develop approaches for evenly distributing the demand for power in the northern regions and will ensure the constant load and stability of the power system from renewable energy sources. The same results will be used for the correct selection of RES. 


\section{7- Funding}

The work was supported by the Ministry of Science and Higher Education, contact № 0825-2020-0014.

\section{8- Conflict of Interest}

The author declares that there is no conflict of interests regarding the publication of this manuscript. In addition, the ethical issues, including plagiarism, informed consent, misconduct, data fabrication and/or falsification, double publication and/or submission, and redundancies have been completely observed by the authors.

\section{9- References}

[1] Anisimov, I A, A D Burakova, and L N Burakova. "Increasing the Efficiency of Electricity Production from Renewable Sources for Charging Electric Vehicles.” 2018 International Multi-Conference on Industrial Engineering and Modern Technologies (FarEastCon) (October 2018). doi:10.1109/fareastcon.2018.8602620.

[2] Burakova, A. D., L. N. Burakova, I A. Anisimov, and O D Burakova. "Evaluation of the Operation Efficiency of Solar Panels in winter." IOP Conference Series: Earth and Environmental Science 72 (June 2017): 012022. doi:10.1088/17551315/72/1/012022.

[3] Hysa, Azem. "Modeling and Simulation of the Photovoltaic Cells for Different Values of Physical and Environmental Parameters.” Emerging Science Journal 3, no. 6 (December 1, 2019): 395-406. doi:10.28991/esj-2019-01202.

[4] IRENA (2018). Renewable capacity statistics 2018. Available online: https://www.irena.org/publications/2018/ Mar/Renewable-Capacity-Statistics-2018 (accessed on June 2020).

[5] IRENA (2019). A report from the international renewable energy agency to the G20 climate sustainability working group. Available online: https://www.irena.org/-/media/Files/IRENA/Agency/Publication/2019/Jun/IRENA_G20_climate_ sustainability _ 2019.pdf (accessed on June 2020).

[6] IRENA (2019). Innovation outlook: Smart charging for electric vehicles. Available online: https://www.irena.org/publications/ 2019/May/Innovation-Outlook-Smart-Charging. (Accessed on June 2020).

[7] Gorbunova, A D, I A Anisimov, A A Fadyushin, M Tishin, and D A Zakharov. "Assessment of Modern Technology Influence in the Transport Industry to Reduce Carbon Dioxide Emissions." IOP Conference Series: Earth and Environmental Science 224 (February 5, 2019): 012050. doi:10.1088/1755-1315/224/1/012050.

[8] Anisimov, I A, A D Gorbunova, L N Burakova, and O D Burakova. "Evaluation of the Effectiveness of the Adaptive Traffic Management System for Its Development and Interaction with Electric Transport." IOP Conference Series: Earth and Environmental Science 177 (August 10, 2018): 012013. doi:10.1088/1755-1315/177/1/012013.

[9] IRENA (2019). Innovation landscape brief: Electric-vehicle smart charging. Available online: https://irena.org//media/Files/IRENA/Agency/Publication/2019/Sep/IRENA_EV_smart_charging_2019.pdf?la=en\&hash=E77FAB7422226D29 931E8469698C709EFC13EDB2. (Accessed on June 2020).

[10] IRENA (2016). The Renewable Route to Sustainable Transport: A Working Paper based on Remap. Available online: https://irena.org/publications/2016/Aug/The-Renewable-Route-to-Sustainable-Transport-A-working-paper-based-onRemap. (Accessed on June 2020).

[11] Frade, Inês, Anabela Ribeiro, Gonçalo Gonçalves, and António Pais Antunes. "Optimal Location of Charging Stations for Electric Vehicles in a Neighborhood in Lisbon, Portugal." Transportation Research Record: Journal of the Transportation Research Board 2252, no. 1 (January 2011): 91-98. doi:10.3141/2252-12.

[12] Giménez-Gaydou, Diego A., Anabela S. N. Ribeiro, Javier Gutiérrez, and António Pais Antunes. "Optimal Location of Battery Electric Vehicle Charging Stations in Urban Areas: A New Approach.” International Journal of Sustainable Transportation 10, no. 5 (December 24, 2014): 393-405. doi:10.1080/15568318.2014.961620.

[13] Mak, Ho-Yin, Ying Rong, and Zuo-Jun Max Shen. "Infrastructure Planning for Electric Vehicles with Battery Swapping." Management Science 59, no. 7 (July 2013): 1557-1575. doi:10.1287/mnsc.1120.1672.

[14] Daskin, Mark S. "What You Should Know About Location Modeling.” Naval Research Logistics 55, no. 4 (2008): $283-294$. doi:10.1002/nav.20284.

[15] Daskin, Mark S. Network and discrete location: models, algorithms, and applications. New Jersey: John Wiley \& Sons, 2013.

[16] Araujo Scharnberg, Allan Ramone, Adrison Carvalho de Loreto, and Annelise Kopp Alves. "Optical and Structural Characterization of Bi2FexNbO7 Nanoparticles for Environmental Applications.” Emerging Science Journal 4, no. 1 (February 1, 2020): 11-17. doi:10.28991/esj-2020-01205.

[17] Birnie, Dunbar P. "Solar-to-Vehicle (S2V) Systems for Powering Commuters of the Future.” Journal of Power Sources 186, no. 2 (January 2009): 539-542. doi:10.1016/j.jpowsour.2008.09.118. 
[18] Li, Chenxi, Fengji Luo, Yingying Chen, Zhao Xu, Yinan An, and Xiao Li. "Smart Home Energy Management with Vehicleto-Home Technology." 2017 13th IEEE International Conference on Control \& Automation (ICCA) (July 2017). doi:10.1109/icca.2017.8003048.

[19] Yoshimi, K., M. Osawa, D. Yamashita, T. Niimura, R. Yokoyama, T. Masuda, H. Kondou, and T. Hirota. "Practical Storage and Utilization of Household Photovoltaic Energy by Electric Vehicle Battery." 2012 IEEE PES Innovative Smart Grid Technologies (ISGT) (January 2012). doi:10.1109/isgt.2012.6175688.

[20] Mahmud, K., S. Morsalin, Y. R. Kafle, and G. E. Town. "Improved Peak Shaving in Grid-Connected Domestic Power Systems Combining Photovoltaic Generation, Battery Storage, and V2G-Capable Electric Vehicle." 2016 IEEE International Conference on Power System Technology (POWERCON) (September 2016). doi:10.1109/powercon.2016.7753990.

[21] Rahman, Imran, Pandian M. Vasant, Balbir Singh Mahinder Singh, M. Abdullah-Al-Wadud, and Nadia Adnan. "Review of Recent Trends in Optimization Techniques for Plug-in Hybrid, and Electric Vehicle Charging Infrastructures." Renewable and Sustainable Energy Reviews 58 (May 2016): 1039-1047. doi:10.1016/j.rser.2015.12.353.

[22] Deilami, Sara, Amir S. Masoum, Paul S. Moses, and Mohammad A. S. Masoum. "Real-Time Coordination of Plug-In Electric Vehicle Charging in Smart Grids to Minimize Power Losses and Improve Voltage Profile.” IEEE Transactions on Smart Grid 2, no. 3 (September 2011): 456-467. doi:10.1109/tsg.2011.2159816.

[23] Liu, Jian. "Electric Vehicle Charging Infrastructure Assignment and Power Grid Impacts Assessment in Beijing." Energy Policy 51 (December 2012): 544-557. doi:10.1016/j.enpol.2012.08.074.

[24] Masoum, A.S., S. Deilami, P.S. Moses, M.A.S. Masoum, and A. Abu-Siada. "Smart Load Management of Plug-in Electric Vehicles in Distribution and Residential Networks with Charging Stations for Peak Shaving and Loss Minimisation Considering Voltage Regulation.” IET Generation, Transmission \& Distribution 5, no. 8 (2011): 877. doi:10.1049/ietgtd.2010.0574.

[25] Shahid, Sofia, Karthik Ram Narumanchi, and Deniz Gurkan. "Plug-in Electric Vehicle Battery Sensor Interface in Smart Grid Network for Electricity Billing." 2012 IEEE Sensors Applications Symposium Proceedings (February 2012). doi:10.1109/sas.2012.6166314.

[26] Simonov, Mikhail. "Mastering Cooperation: Electric Vehicle and Smart Grid." 2011 11th International Conference on ITS Telecommunications (August 2011). doi:10.1109/itst.2011.6060105.

[27] Lam, Albert Y.S., Longbo Huang, Alonso Silva, and Walid Saad. “A Multi-Layer Market for Vehicle-to-Grid Energy Trading in the Smart Grid.” 2012 Proceedings IEEE INFOCOM Workshops (March 2012). doi:10.1109/infcomw.2012.6193525.

[28] Drude, Lukas, Luiz Carlos Pereira Junior, and Ricardo Rüther. "Photovoltaics (PV) and Electric Vehicle-to-Grid (V2G) Strategies for Peak Demand Reduction in Urban Regions in Brazil in a Smart Grid Environment.” Renewable Energy 68 (August 2014): 443-451. doi:10.1016/j.renene.2014.01.049.

[29] Singh, M., P. Kumar, and I. Kar. "A Model of Electric Vehicle Charging Station Compatibles with Vehicle to Grid Scenario." 2012 IEEE International Electric Vehicle Conference (March 2012). doi:10.1109/ievc.2012.6183223.

[30] Gurkaynak, Yusuf, and Alireza Khaligh. "Control and Power Management of a Grid Connected Residential Photovoltaic System with Plug-in Hybrid Electric Vehicle (PHEV) Load.” 2009 Twenty-Fourth Annual IEEE Applied Power Electronics Conference and Exposition (February 2009). doi:10.1109/apec.2009.4802962.

[31] Carli, Giampaolo, and Sheldon S. Williamson. "Technical Considerations on Power Conversion for Electric and Plug-in Hybrid Electric Vehicle Battery Charging in Photovoltaic Installations.” IEEE Transactions on Power Electronics 28, no. 12 (December 2013): 5784-5792. doi:10.1109/tpel.2013.2260562.

[32] Domínguez-Navarro, J.A., R. Dufo-López, J.M. Yusta-Loyo, J.S. Artal-Sevil, and J.L. Bernal-Agustín. "Design of an Electric Vehicle Fast-Charging Station with Integration of Renewable Energy and Storage Systems." International Journal of Electrical Power \& Energy Systems 105 (February 2019): 46-58. doi:10.1016/j.ijepes.2018.08.001.

[33] Apajalahti, Eeva-Lotta, Armi Temmes, and Tea Lempiälä. "Incumbent Organisations Shaping Emerging Technological Fields: Cases of Solar Photovoltaic and Electric Vehicle Charging." Technology Analysis \& Strategic Management 30, no. 1 (February 9, 2017): 44-57. doi:10.1080/09537325.2017.1285397.

[34] Pan, Feng, Russell Bent, Alan Berscheid, and David Izraelevitz. "Locating PHEV Exchange Stations in V2G." 2010 First IEEE International Conference on Smart Grid Communications (October 2010). doi:10.1109/smartgrid.2010.5622037.

[35] Kibaara, Samuel Kariuki, D. K. Murage, P. Musau, and M. J. Saulo. "Comparative Analysis of Implementation of Solar PV Systems Using the Advanced SPECA Modelling Tool and HOMER Software: Kenyan Scenario.” HighTech and Innovation Journal 1, no. 1 (March 1, 2020): 8-20. doi:10.28991/hij-2020-01-01-02.

[36] Pashajavid, E., and M. A. Golkar. "Optimal Placement and Sizing of Plug in Electric Vehicles Charging Stations within Distribution Networks with High Penetration of Photovoltaic Panels.” Journal of Renewable and Sustainable Energy 5, no. 5 (September 2013): 053126. doi:10.1063/1.4822257. 
[37] Farkas, Csaba, and László Prikler. "Stochastic Modelling of EV Charging at Charging Stations.” Renewable Energy and Power Quality Journal (April 2012): 1046-1051. doi:10.24084/repqj10.574.

[38] Li, Ruqi, and Haoyi Su. "Optimal allocation of charging facilities for electric vehicles based on queuing theory." Dianli Xitong Zidonghua(Automation of Electric Power Systems) 35, no. 14 (2011): 58-61.

[39] Liu, Xiyuan, and Zhaohong Bie. "Optimal Allocation Planning for Public EV Charging Station Considering AC and DC Integrated Chargers.” Energy Procedia 159 (February 2019): 382-387. doi:10.1016/j.egypro.2018.12.072.

[40] Conti, Valentina, Silvia Orchi, Maria Pia Valentini, Marialisa Nigro, and Raffaella Calò. "Design and Evaluation of Electric Solutions for Public Transport.” Transportation Research Procedia 27 (2017): 117-124. doi:10.1016/j.trpro.2017.12.033.

[41] Pternea, Moschoula, Konstantinos Kepaptsoglou, and Matthew G. Karlaftis. "Sustainable Urban Transit Network Design." Transportation Research Part A: Policy and Practice 77 (July 2015): 276-291. doi:10.1016/j.tra.2015.04.024.

[42] Kunith, Alexander, Roman Mendelevitch, and Dietmar Goehlich. "Electrification of a City Bus network-An Optimization Model for Cost-Effective Placing of Charging Infrastructure and Battery Sizing of Fast-Charging Electric Bus Systems." International Journal of Sustainable Transportation 11, no. 10 (March 30, 2017): 707-720. doi: 10.1080/15568318.2017.1310962.

[43] Calise, Francesco, Francesco Liberato Cappiello, Armando Cartenì, Massimo Dentice d'Accadia, and Maria Vicidomini. "A Novel Paradigm for a Sustainable Mobility Based on Electric Vehicles, Photovoltaic Panels and Electric Energy Storage Systems: Case Studies for Naples and Salerno (Italy)." Renewable and Sustainable Energy Reviews 111 (September 2019): 97-114. doi:10.1016/j.rser.2019.05.022.

[44] Sun, Xiaoli, Zhengguo Li, Xiaolin Wang, and Chengjiang Li. "Technology Development of Electric Vehicles: A Review." Energies 13, no. 1 (December 23, 2019): 90. doi:10.3390/en13010090.

[45] Wang, Zhenpo, Peng Liu, Jia Cui, Yue Xi, and Lei Zhang. "Research on Quantitative Models of Electric Vehicle Charging Stations Based on Principle of Energy Equivalence." Mathematical Problems in Engineering 2013 (2013): 1-10. doi:10.1155/2013/959065.

[46] Wolbertus, Rick, and Robert Van den Hoed. "Electric Vehicle Fast Charging Needs in Cities and Along Corridors." World Electric Vehicle Journal 10, no. 2 (June 18, 2019): 45. doi:10.3390/wevj10020045.

[47] Fusco, Gaetano, Adriano Alessandrini, Chiara Colombaroni, and Maria Pia Valentini. "A Model for Transit Design with Choice of Electric Charging System." Procedia - Social and Behavioral Sciences 87 (October 2013): 234-249. doi:10.1016/j.sbspro.2013.10.607.

[48] De Filippo, Giovanni, Vincenzo Marano, and Ramteen Sioshansi. "Simulation of an Electric Transportation System at the Ohio State University.” Applied Energy 113 (January 2014): 1686-1691. doi:10.1016/j.apenergy.2013.09.011. 